\title{
Development of a New Approach for Standardization of the Herb Centaurium erythraea Rafn. by High Performance Liquid Chromatography
}

\author{
Centaurium erythraea Rafn. Bitkisinin Yüksek Basınçlı Sıvı Kromatografisi \\ Yöntemi ile Standardizasyonu İçin Yeni Bir Yaklaşımın Geliştirilmesi
}

\author{
(D) Svitlana M. GUBAR1, (D) Anna S. MATERIIENKO2*, (D) Nataliia M. SMIELOVA¹, (D) Liana G. BUDANOVA³, (D) Victoriya A. GEORGIYANTS1 \\ 1National University of Pharmacy, Department of Pharmaceutical Chemistry, Kharkiv, Ukraine \\ 2National University of Pharmacy, Department of Quality, Standardization and Certification of Medicines, Kharkiv, Ukraine \\ 3National University of Pharmacy, Department of Foreign Languages, Kharkiv, Ukraine
}

\section{ABSTRACT}

Objectives: The aim of this study was the development a new, fully validated high performance liquid chromatography (HPLC) method for the quantitative analysis of secoiridoid glycosides by an active marker swertiamarin in the herb Centaurium erythraea Rafn. The article describes a new approach to the standardization of $C$. erythraea and more specifically the development of a new validated HPLC method for the quantitative determination of secoiridoid glycosides by swertiamarin.

Materials and Methods: The quantitative determination of swertiamarin was performed in isocratic mode on a Symmetry C18 column using water and acetonitrile as solvents for the mobile phase.

Results: Validation characteristics of the developed method showed that it was linear in the whole range of concentrations from $0.01 \mathrm{mg} / \mathrm{mL}$ to 0.05 $\mathrm{mg} / \mathrm{mL}$ swertiamarin. All validation characteristics met the established acceptance criteria.

Conclusion: This method can be used in the standardization of raw materials, as well as in the analysis of medicinal products and dietary supplements that include $C$. erythraea. The established chromatographic method was successfully applied for the analysis of raw materials of $C$. erythraea with the quantitative content determination of swertiamarin in the analyzed samples.

Key words: Common centaury herb, method development, HPLC, swertiamarin, validation

öz

Amaç: Bu çalışmanın amacı, Centaurium erythraea Rafn. bitkisinde bulunan sekoiridoidleri glikozitlerinin aktif göstergesi olan swertiamarinin yeni, tam valide bir yüksek basınçlı sıvı kromatografisi (HPLC) yöntemiyle kantitatif analizidir. Bu makale C. erythraea'nın standardizasyonunu ve daha spesifik olarak da swertiamarin ile sekoiridoid glikozitlerini yeni valide HPLC yöntemi geliştirerek kantitatif olarak belirlenmesinden söz etmektedir. Gereç ve Yöntemler: Swertiamarinin kantitatif belirlenmesi mobil faz için su ve asetonitril kullanılarak bir Symmetry C18 kolonu üzerinde izokratik modda yapılmıştır.

Bulgular: Geliștirilen yöntemin validasyon karakteristikleri $0,01 \mathrm{mg} / \mathrm{mL}$ swertiamarinden $0,05 \mathrm{mg} / \mathrm{mL}$ swertiamarine dek olan geniş bir konsantrasyon aralığında yöntemin doğrusal olduğunu göstermiştir. Tüm validasyon karakteristikleri kabul edilebilir kriterlere uymuştur.

Sonuç: Bu yöntem, C. erythraea içeren hammadde ve medisinal ürünler ve diyetsel suplemanların analizinde standardizasyon için kullanılabilir. Bu kromatografik yöntem analiz edilen C. erythraea'nın hammaddelerine swertiamarinin kalitatif içeriğini başarılı bir şekilde belirlenmesi için uygulanmıştır.

Anahtar kelimeler: Kantaron bitkisi, yöntem geliștirme, HPLC, swertiamarin, validasyon

*Correspondence: E-mail: anna.materienko@gmail.com, Phone: +380971142384 ORCID-ID: orcid.org/0000-0003-4184-2944

Received: 24.05.2019, Accepted: 17.10.2019

-Turk J Pharm Sci, Published by Galenos Publishing House. 


\section{INTRODUCTION}

Centaurium erythraea Rafn. is a valuable source of various biologically active compounds (BACs), including bitters.' Due to the presence of this particular group of BACs, the plant is widely used to treat diseases of the gastrointestinal tract and is included in the composition of drugs and dietary supplements. ${ }^{2}$ The main representatives of secoiridoid glycosides, which determine the pharmacological action of this raw material, are swertiamarin, sweroside, and gentiopicroside (Figure 1).<smiles>C=CC1C(OCl)OCC2C(=O)OC[C@H](O)C21</smiles>

Swertiamarin<smiles>C=CC1C(OC)OC=C2C(=O)OC[CH]C21</smiles>

Sweroside<smiles>C=CC1C2=CCOC(=O)C2=COC1OC</smiles>

Gentiopicroside
Figure 1. Structural formulas of secoiridoid glycosides of centaury

Bitters improve intestinal motility, increase the reduced secretory function of the stomach, and are used in the treatment of hypoacidic and chronic atrophic gastritis as well. In addition, secoiridoid glycosides show anti-inflammatory and antibacterial activity. ${ }^{3}$

The results of studies on the biological action of a secoiridoid glycoside of centaury, namely swertiamarin, are widely described in the literature. It has antihyperlipidemic, ${ }^{4}$ hypoglycemic, ${ }^{5}$ insulinotropic, ${ }^{6,7}$ and antinociceptive ${ }^{8}$ actions. In addition, swertiamarin exhibits an anticholinergic effect ${ }^{9}$ and depressant effect, inhibits human DNA lipase, and has a central nervous system depressant effect $t^{10}$ as well as inhibiting the growth of Bacillus cereus, Bacillus subtilis, Citrobacter freundii, Escherichia coli, Proteus mirabilis, and Serratia marcescens. ${ }^{2}$

It is important to mention that there are only a few publications regarding the description of the methods of $C$. erythraea analysis. Kaluzova et al."1 described the analysis of gentiopicroside by high performance liquid chromatography (HPLC) in C. erythraea. Valentao et al.12 analyzed xanthones (validation is not described). Glatz et al. ${ }^{13}$ described the method for determining gentiopicroside in extracts of $C$. erythraea using micellar electrokinetic capillary chromatography, and Nikolova-Damyanova and Handjieva ${ }^{14}$ carried out a quantitative determination of swertiamarin and gentiopicroside using the densitometric method.

In the European Pharmacopoeia, there are no methods for the quantitative analysis of secoiridoid glycosides in this raw material..$^{5}$ In the article on centaury for the quantitative evaluation of raw materials it is suggested to use the pharmacognosy method "Bitterness value", an organoleptic method of determination, which is based on the individual sensitivity of taste receptors and the subjective assessment of each expert.
The rate of bitterness represents the reciprocal dilution of the mixture, liquid, or extract, which still has a bitter taste. This indicator is determined by comparison with quinine hydrochloride, whose rate of bitterness is 200,000 (Eur.Ph. 2.8.15). This method is characterized by great subjectivity and high inaccuracy of determination, which means it is not recommended for the analysis of raw materials in modern conditions.

In the literature it is also stated that secoiridoid glycosides have different values of bitterness. ${ }^{15}$ It is proved that swertiamarin is not the most bitter of them, and such a method, as a bitterness value, does not allow the objective evaluation of the content of swertiamarin in raw materials.

The European Pharmacopoeia ${ }^{16}$ suggests the use of swertiamarin as a marker compound during the test "Identification" by the thin-layer chromatography method. Based on this, as well as on the results of the study of its biological activity, we suggested choosing swertiamarin as an active marker in the development of methods for standardization of $C$. erythraea.

The literature describes approaches for the quantitative determination of swertiamarin in other types of raw materials, such as its estimation in Enicostemma littorale ${ }^{17}$ and its analysis in different Swertia species. ${ }^{18}$ When developing the methodology, all the described approaches to the analysis of swertiamarin were studied and a new selective, sensitive, and accurate HPLC method for its quantitative determination in C. erythraea was developed. The most optimal conditions for the quantitative analysis of swertiamarin in the common centaury herb by the HPLC method are proposed: isocratic elution mode and more acceptable chromatographic time, based on the characteristics of this raw material in order to ensure maximum specificity (exclusion of influence on the analysis of ballast substances and other BAS groups of this raw material).

During the course of the experiment, a new, fully validated method was developed for the quantitative analysis of secoiridoid glycosides by the active marker swertiamarin in C. erythraea by HPLC method. This method can be used in the standardization of raw materials, as well as in the analysis of medicinal products and dietary supplements that include $C$. erythraea.

\section{MATERIALS AND METHODS}

\section{HPLC}

Quantitative analysis of swertiamarin in C. erythraea was carried out on a ProStar liquid chromatograph equipped with an autosampler 410 and two detectors, spectrophotometric PDA 325 and photodiode array detector PDA 330, made by Varian (USA). A Symmetry C18 column (150x4.6 mm, particle size 3.5 $\mu \mathrm{m})$ with a precolumn was also used. A mixture of water and acetonitrile at the ratio of 91:9 was used as the mobile phase. The separation was carried out in isocratic mode. The flow rate of the mobile phase was $1 \mathrm{~mL} / \mathrm{min}$, the injection volume was 20 $\mu \mathrm{L}$, the detection was carried out at a wavelength of $238 \mathrm{~nm}$, and the column temperature was $40^{\circ} \mathrm{C}$. 
The sampling was carried out on an analytical balance, Ohaus Adventurer brand AR2140 (USA), by standard procedure for raw materials, according to the European Pharmacopoeia (Eur. Ph. 2.9.12). During the sample preparation, the following items were also used: a 355 sieve (SL-200) and a medical laboratory centrifuge with a rotor RU-180 OPN-12 “OAO TNK DASTAN".

\section{Raw materials and reagents}

To conduct the research, 20 series of $C$. erythraea plants were collected in various regions of Ukraine during the flowering period. Macroscopic and microscopic identification of raw materials was carried out at the Department of Botany of the National University of Pharmacy, Ukraine. The plant species were deposited in the herbarium section of the same department (code - BDC 12703).

The following reagents were used: acetonitrile (Sigma Aldrich, gradient grade, for HPLC), methanol (Sigma Aldrich, gradient grade, for HPLC), and water for chromatography (Millipore). A standard sample of swertiamarin (purity 99.5\%), series OS10475 (Carbosynth, UK), was also used.

Solutions for the analysis were prepared according to the following methods:

Test solution: $0.500 \mathrm{~g}$ (accurately weighed) of the powdered raw material (355 $\mu \mathrm{m}$, Eur.Ph. 2.9.12) was supplemented with $20 \mathrm{~mL}$ of methanol, shaken for $15 \mathrm{~min}$, and centrifuged and the supernatant was removed into a $50-\mathrm{mL}$ volumetric flask. The extraction was repeated with a further $20 \mathrm{~mL}$ of methanol, with collection of the supernatant as before. The volume of the solution was made up to the mark with methanol and mixed. Then $10 \mathrm{~mL}$ of the obtained solution was diluted to $50 \mathrm{~mL}$ with water. The solution was filtered through a $0.45 \mu \mathrm{m}$ membrane filter.

Reference solution: $0.010 \mathrm{~g}$ of swertiamarin (accurately weighed) was placed into a $100 \mathrm{~mL}$ volumetric flask, dissolved in $50 \mathrm{~mL}$ of methanol, and then the volume was made up to the mark with the same solvent and mixed. Then $10 \mathrm{~mL}$ of the obtained solution was diluted to $50 \mathrm{~mL}$ with water, mixed, and filtered through a $0.45 \mu \mathrm{m}$ membrane filter.

\section{Validation}

Validation of the developed method was carried out in accordance with the recommendations of the $\mathrm{ICH}^{19}$ the requirements of article 2.2.N.2 of $\mathrm{SPhU},{ }^{20}$ and the standard procedure of quantitative methods validation using an external standard by studying its linearity, as well as its accuracy, robustness, and precision.

To study the specificity, the following solutions were prepared: a blank solution, a reference solution (a solution of a standard sample of swertiamarin), and a test solution.

To confirm the linearity of the method, five model solutions were prepared, the concentration of which varied uniformly within the application range to the extent of $50-250 \%$ (step $50 \%)$.

To determine the accuracy and precision within the range of use of the analytical method, five test solutions were prepared, in compliance with all the stages of the analytical procedure. The concentration of swertiamarin in the prepared solutions ranged from $0.01 \mathrm{mg} / \mathrm{mL}$ to $0.05 \mathrm{mg} / \mathrm{mL}$.

In order to determine the intra-laboratorial precision, one sample was examined six times by two analysts on different days during one working week using various measuring glassware.

\section{Statistical analysis}

The analytical performance of the HPLC method was verified for compliance with the requirements. All tests were performed on three replicate injections and standard deviations for each analysis were calculated.

\section{RESULTS AND DISCUSSION}

\section{Analysis of medicinal plant raw materials}

An HPLC method was developed for analyzing the quality control of the medicinal plant raw material, C. erythraea. Swertiamarin was chosen as the active marker. It is suggested for the standardization of the raw material, as it was previously established that centaury contained the highest amount of swertiamarin and other secoiridoid glycosides, such as sweroside and gentiopicroside, in smaller amounts. ${ }^{21}$

The HPLC method for analyzing secoiridoid glycosides in centaury was developed on the basis of the State Research Laboratory for Quality Control of Medicines of the NUPh.

The results of quantitative determination of the swertiamarin content in the analyzed samples of the medicinal plant raw materials are shown in Table 1.

\section{Statistical analysis}

\section{Method validation}

When choosing the criterion for rationing the quantitative content of swertiamarin in the centaury, we used the results of the analysis of the raw materials for all indicators applicable to medicinal plant raw materials. It was found that the raw materials, in which the content of swertiamarin was less than $3 \%$, did not meet the requirements of the Pharmacopoeia for such parameters as "foreign matter" and "total ash". On this basis, the quantitative content of swertiamarin in the centaury was not less than $3 \%$ in terms of dried raw materials. The results obtained during the analysis showed that 15 series of raw materials met these requirements.

The total uncertainty of the developed method was calculated, which in this case is related to the limits of the analyte content in the medicinal plant raw materials. For the centaury, the established content of swertiamarin is normalized at a level of at least $3 \%$. In accordance with the requirements of SPhU 2.0 for quantitative determination (one-sided rationing "no more"), the maximum permissible total uncertainty of the analysis method is $\max \Delta_{A S}\left\langle 6.4 \% .^{17}\right.$

The criterion of insignificance compared with the maximum permissible uncertainty of the results is $\left(\Delta_{A S \text {, insig }}\right): \Delta_{A S \text {, }}$ insig $\leq \max \Delta_{A S^{\prime}} \%{ }^{*} 0.32=6.4 \%{ }^{*} 0.32=2.048 \%$. 
Table 1. The results of experimental studies of the swertiamarin content in centaury by HPLC method

\begin{tabular}{|c|c|c|}
\hline No series & $\begin{array}{l}\text { The region of collection of raw } \\
\text { materials }\end{array}$ & $\begin{array}{l}\text { Quantitative content of } \\
\text { swertiamarin, \% }\end{array}$ \\
\hline 1 & 2 & 3 \\
\hline 1 & Dnipropetrovsk region & 3.6 \\
\hline 2 & Dnipropetrovsk region & 3.9 \\
\hline 3 & Dnipropetrovsk region & 1.7 \\
\hline 4 & Ivano-Frankivsk region & 7.7 \\
\hline 5 & Kharkov region & 4.5 \\
\hline 6 & Kharkov region & 6.4 \\
\hline 7 & Kharkov region & 2.8 \\
\hline 8 & Kiev region & 8.3 \\
\hline 9 & Lviv region & 7.3 \\
\hline 10 & Lviv region & 4.8 \\
\hline 11 & Lviv region & 2.4 \\
\hline 12 & Poltava region & 6.6 \\
\hline 13 & Poltava region & 7.1 \\
\hline 14 & Poltava region & 1.5 \\
\hline 15 & Rovenskaya region & 9.1 \\
\hline 16 & Sumy region & 7.8 \\
\hline 17 & Sumy region & 8.4 \\
\hline 18 & Sumy region & 2.2 \\
\hline 19 & Volyn region & 7.8 \\
\hline 20 & Volyn region & 6.0 \\
\hline
\end{tabular}

HPLC: High performance liquid chromatography

The calculation of the uncertainty of the final analytical operation $\Delta_{F A O}$ was carried out for the test solution and the reference solution. When calculating the intervals, Student's one-sided coefficient was used for a probability of $95 \%$ and the corresponding number of freedom degrees. Confidence intervals for the reference solution and the testing solution were calculated for an average of five results.

According to the requirements of suitability of the chromatographic system in the determination procedure, the relative standard deviation for five parallel determinations should be no more than $2.0 \%$.

When $n=5$, $t(95 \%, n-1)=2.1318$ :

$\Delta_{\mathrm{FAO}}^{\mathrm{m}}=\frac{1}{\sqrt{5}} * 2.1318 * 2.0 \%=1,907 \% \Delta_{\mathrm{FAO}}^{\mathrm{mp}}=\frac{1}{\sqrt{5}} * 2.1318 * 2.0 \%=1.907 \%$

The total uncertainty of the final analytical operation:

$\Delta_{\mathrm{FAO}}^{\mathrm{cm}}=\sqrt{\left(\Delta_{\mathrm{FA}}^{\mathrm{mp}}\right)^{2}+\left(\Delta_{\mathrm{FAO}}^{\mathrm{m}}\right)^{2}}=2.70 \%$

Complete uncertainty of the analysis techniques $\Delta_{A S} \%$ :

$\Delta_{A S}=\sqrt{\left(\Delta_{s p}\right)^{2}+\left(\Delta_{\text {FAA }}\right)^{2}}=3.39 \%$
Thus, the calculated total uncertainty of the analysis $\Delta_{A S} \%$ is less than $\max \Delta_{A S}\left(3.39 \%<\max \Delta_{A S}=6.4 \%\right)$, which meets the requirements for this parameter.

\section{Specificity}

Under the conditions of the developed method, the determination of the active substance of swertiamarin was not interfered with by the solvent or the mobile phase, or other co-eluting impurities from the raw material at a detection wavelength of $238 \mathrm{~nm}$, which indicates the specificity of the developed method.

Chromatograms of the blank solution, the test solution, and the reference solution are shown in Figure 2 in order to confirm the specificity of the method.

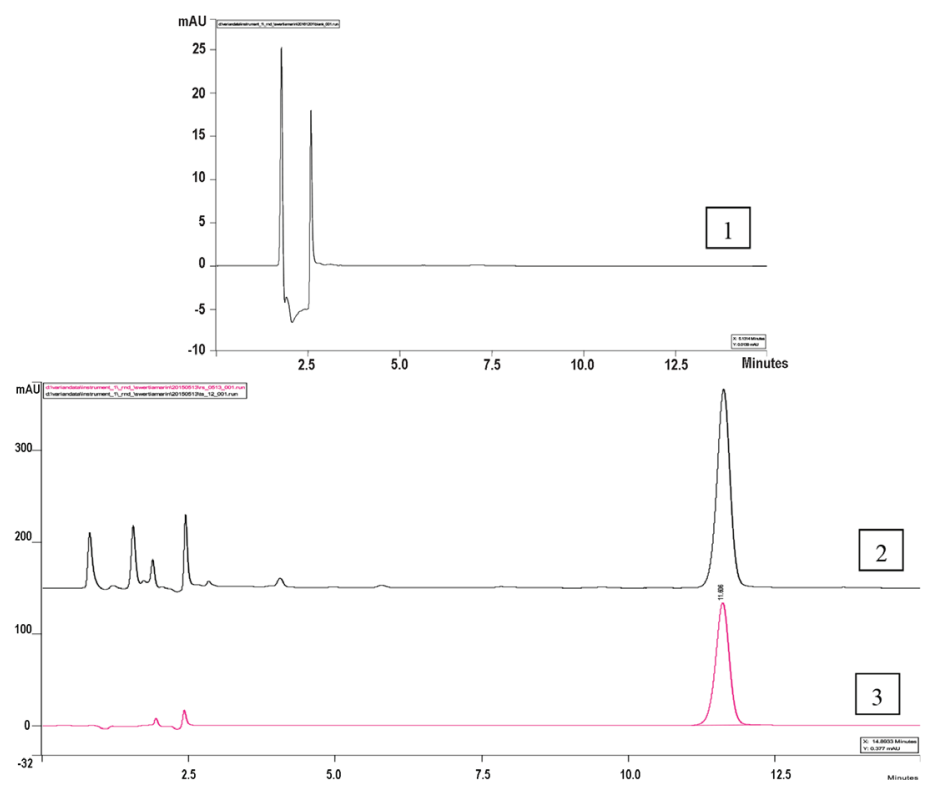

Figure 2. Chromatograms of the blank solution 1), the test solution 2), and reference solution 3 )

\section{Linearity}

The method of quantification must be linear within the application range and must cover the possible values of the active substance concentrations. According to the requirements of the State Pharmacopoeia of Ukraine, the application range of the method of quantitative determination of swertiamarin in the medicinal plant raw materials must be from $50 \%$ to $250 \%$.

Chromatograms of the solutions studied are shown in Figure 3.

The linearity curve is presented in Figure 4.

The linearity parameters, which are presented in Table 2, indicate the linearity of the method within the test range.

The results obtained confirm that the method developed for the quantitative determination of swertiamarin by HPLC in the concentration range from $0.01 \mathrm{mg} / \mathrm{mL}$ to $0.05 \mathrm{mg} / \mathrm{mL}$ is linear.

Accuracy, precision, and intermediate precision

Accuracy is characterized by two criteria:

- Criterion of statistical insignificance: $\delta \%=\left|Z-100 \leq \frac{\Delta z}{\sqrt{5}}\right|$ 


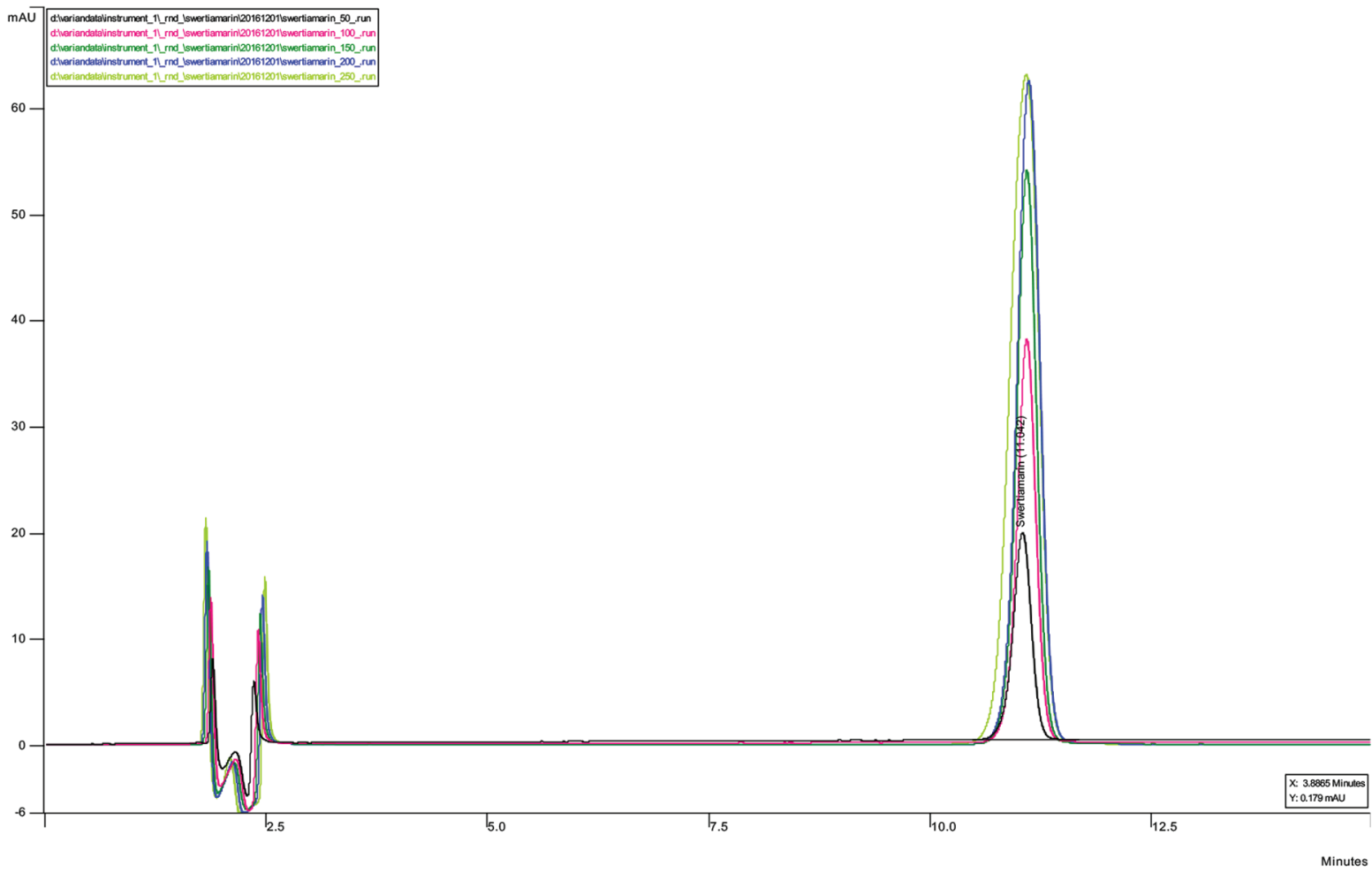

Figure 3. Chromatogram of swertiamarin solutions for linearity determination in the concentration range from $0.01 \mathrm{mg} / \mathrm{mL}$ to $0.05 \mathrm{mg} / \mathrm{mL}$

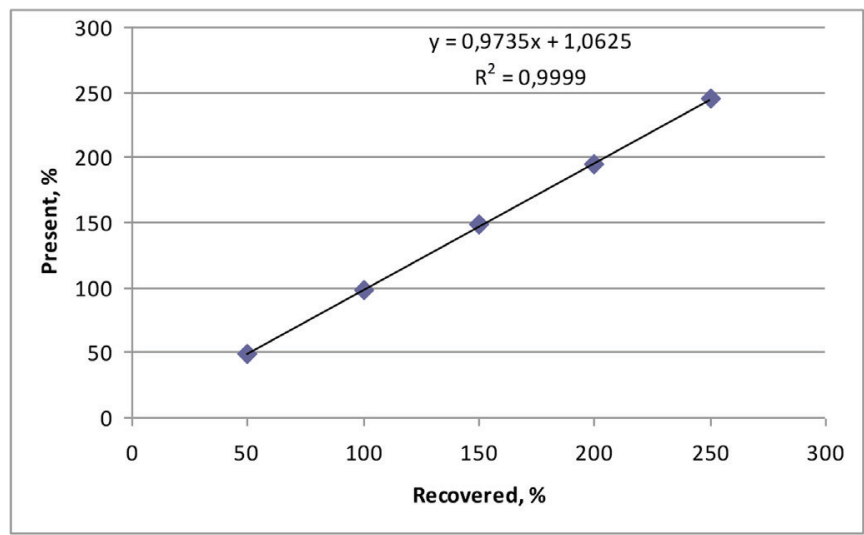

Figure 4. The linearity curve of swertiamarin concentration by HPLC method

HPLC: High performance liquid chromatography

$\delta \%$ - criterion of practical insignificance - in the case the above ratio is not satisfied, we must use the criterion of insignificance of this systematic error compared with the maximum allowable uncertainty of the analysis:

$|\bar{Z}-100| \leq \Delta_{A S, \text { in sing }}=2.048 \%$

The fulfillments of the criteria of accuracy, precision, and intermediate precision for determining swertiamarin in the common centaury herb by HPLC are given in Table 3.

The method of determining swertiamarin in centaury satisfies the criteria for acceptability of the validity indicators accuracy, precision, and intermediate precision.

$\begin{aligned} & \text { Table 2. The linearity parameters of the quantitative determination } \\
& \text { method }\end{aligned}$
\begin{tabular}{lllll} 
No & Parameter & Requirements & Received value & Criterion fulfillment \\
\hline 1 & lal & $\leq 5.1$ & 1.0625 & Performing \\
\hline 2 & $S_{0}$ & $\leq 3.4$ & 0.67 & Performing \\
\hline 3 & $r$ & $>0.9691$ & 0.9999 & Performing \\
\hline
\end{tabular}

Table 3. The results of the evaluation of the accuracy, precision, and intermediate precision of the HPLC method

\begin{tabular}{lllll} 
Parameter & Index & $\begin{array}{l}\text { Criterion } \\
\text { Requirements } \\
\text { for statistical } \\
\text { insignificance }\end{array}$ & $\begin{array}{l}\text { Requirements } \\
\text { for practical } \\
\text { insignificance }\end{array}$ & $\begin{array}{l}\text { Criterion } \\
\text { fulfillment }\end{array}$ \\
\hline$|\bar{Z}-100|$ & 1.73 & $\leq 0.64 \%$ & $\leq 2.048 \%$ & $\begin{array}{l}\text { Performing } \\
\text { by the second } \\
\text { criteria }\end{array}$ \\
\hline$\Delta Z$ & 1.428 & $\leq 6.4 \%$ & Performing \\
\hline$\Delta$ intra & 1.22 & $\leq 6.4 \%$ & Performing \\
\hline
\end{tabular}

\section{Stability}

The study of the stability of the reference solution was carried out immediately after the preparation and $12 \mathrm{~h}$ and $24 \mathrm{~h}$ later. The results are presented in Table 4.

Differences between the obtained values of the swertiamarin content must not exceed the criterion of insignificance in comparison with the maximum permissible uncertainty of the analysis results $\left(\Delta_{A S, \text { insig }}\right)$, that is $2.048 \%$. According to the results of the determination, for optimal chromatographic 
conditions it is necessary to use a freshly prepared comparison solution within $12 \mathrm{~h}$, which means in one working day.

Table 4. Determination of the stability of analytical solutions over time

\begin{tabular}{|l|l|l|}
\multirow{2}{*}{ No model solution } & \multicolumn{2}{l}{ Parameter change, \% } \\
\cline { 2 - 3 } & 12 h later & 24 h later \\
\hline 1 & 1.0214 & 6.1820 \\
\hline 2 & 1.0296 & 5.8819 \\
\hline 3 & 1.0762 & 6.4831 \\
\hline 4 & 1.1395 & 6.1431 \\
\hline 5 & 1.6306 & 6.3427 \\
\hline$\Delta_{\text {ser }}$ & 1.18 & 6.21 \\
\hline
\end{tabular}

\section{CONCLUSION}

This article presents a new method for the quantitative determination of swertiamarin as an active marker for the standardization of raw materials, i.e. C. erythraea. The method developed was fully validated and can be used to control the quality of both the raw material (C. erythraea) and in the analysis of medicinal products and dietary additives that include this plant.

Conflicts of interest: No conflict of interest was declared by the authors. The authors alone are responsible for the content and writing of the paper.

\section{REFERENCES}

1. European Medicines Agency (EMA), Assessment report on Centaurium erythraea Rafn. s.l. including C. majus ( $H$. et L.) Zeltner and C. suffruticosum (Griseb.) Ronn., herba, for the development of a community herbal monograph, Doc. Ref.: EMA/HMPC/105535/2008, 2009. Available from: https://www.ema.europa.eu/en/documents/ herbal-report/superseded-assessment-report-centaurium-erythraearafn-s-l-including-c-majus-h-et-l-zeltner-c_en.pdf

2. Kumarasamy $Y$, Nahar L, Cox PJ, Jaspars M, Sarker SD. Bioactivity of secoiridoid glycosides from Centaurium erythraea. Phytomedicine. 2003;10:344.

3. Tuluce $\mathrm{Y}$, Ozkol H, Koyuncu I,Ine $\mathrm{H}$. Gastroprotective effect of small centaury (Centaurium erythraea $\mathrm{L}$ ) on aspirin-induced gastric damage in rats. Toxicol Ind Health. 2011;27:760-768.

4. Vaidya H, Rajani M, Sudarsanam V, Padh H, Goyal R. Swertiamarin: A lead from Enicostemma littorale Blume. for anti-hyperlipidaemic effect. Eur J Pharmacol. 2009;617:108-112.

5. Patel MB, Mishra SH. Hypoglycemic activity of C-glycosyl flavonoid from Enicostemma hyssopifolium. Pharml Biol. 2011;49:383-391.

6. Vaidya H, Prajapati A, Rajani M, Sudarsanam, V, Padh H, Goyal RK. Beneficial Effects of Swertiamarin on Dyslipidaemia in Streptozotocininduced Type 2 Diabetic Rats. Phytotherapy Research. 2012;26:12591261.

7. Sonawane RD, Vishwakarma SL, Lakshmi S, Rajani M, Padh H, Goyal RK. Amelioration of STZ-induced type 1 diabetic nephropathy by aqueous extract of Enicostemma littorale Blume and swertiamarin in rats. Mol Cell Biochem. 2010;340:1-6.

8. Jaishree V, Badami S. Antioxidant and hepatoprotective effect of swertiamarin from Enicostemma axillare against D-galactosamine induced acute liver damage in rats. J Ethnopharmacol. 2010;130:103106.

9. Yamahara J, Kobayashi M, Matsuda H, Akoi S. Anti-cholinergic action of Swertia japonica and an active constituent. J Ethnopharmcol. 1991;3:3136.

10. Bhattacharya SK, Reddy PK, Ghosal S, Singh AK, Sharma PV. Chemical constituents of Gentinaceae XIX: CNS-depressant effects of swertiamarin. J Pharm Sci. 1976;65:1547-1549.

11. Kaluzova L, Glatz Z, Pospisilova J, Musil P, Unar J. Determination of gentiopicroside in Centaurium erythraea by high-performance liquid chromatography. Cesk Farm. 1995;44:203-205.

12. Valentao P, Andrade PB, Silva E, Vicente A, Santos H, Bastos ML, R.M. Seabra, Methoxylated xanthones in the quality control of small centaury (Centaurium erythraea) flowering tops. J. Agric. Food Chem. 2002;50:460-463

13. Glatz Z, Pospísilová J, Musil P. Determination of gentiopicroside in extracts of Centaurium erythreae and Gentiana lutea by micellar electrokinetic capillary chromatography. J Liq Chromatogr Relat Technol. 2000;23:1831-1839.

14. Nikolova-Damyanova, B, Handjieva N. Quantitative determination of swertiamarin and gentiopicroside in Centaurium erythrea and $\mathrm{C}$. turcicum by densitometry. Phytochemical Analysis. 1996;7:140-142.

15. Sharma Manish K, Mukesh B. Significance of Plant Bitters In The Field of Pharmacognosy. AJPTI. 2013; 01-14

16. European Pharmacopoeia. $9^{\text {th }}$ ed. Strasbourg: European Directorate for the Quality of Medicines Health Care, 2017. Available from: https:// www.edqm.eu/

17. Alam P, Ali M, Singh R, Shakeel F. Estimation of swertiamarin in Enicostemma littorale and marketed formulations using HPLC-UV Method. Journal of Bioanalysis and Biomedicine. 2009;1:22-27.

18. Kshirsagar PR, Pai SR, Nimbalkar MS, Gaikwad NB. RP-HPLC analysis of seco-iridoid glycoside swertiamarin from different Swertia species. Natural product research. 2016;30:865-868.

19. ICH harmonised tripartite guideline Q2(R1). Validation of analytical procedures: text and methodology Q2(R1)," in Proceedings of the International Conference on Harmonization of Technical Requirements for Registration of Pharmaceuticals for Human Use, Geneva, Switzerland, 2005.

20. State Pharmacopoeia of Ukraine: in 3 volumes. Kharkiv: State enterprise "Ukrainian scientific pharmacopoeial center of medicines quality", $2^{\text {nd }}$ ed. Vol. 3., 2014.

21. Gubar S, Materiienko A, Georgiyants V, Vasylieva O, Ivanauskas L. Comparative analysis of the qualitative composition of secoiridoid glycosides in Centaurium erythraea Rafn. and Centaurium pulchellum (Sw) Druce herbs. The $9^{\text {th }}$ International Conference on Pharmaceutical Sciences and Pharmacy Practice, 2018;66. Available from: https:// Ismuni.It/media/dynamic/files/16960/9thconference_science_ practice_1final.pdf 